\title{
Innovation in and from emerging economies: New insights and lessons for international business research
}

\author{
Jaideep Anand ${ }^{1}$, \\ Gerald McDermott ${ }^{2,3}$, \\ Ram Mudambi ${ }^{4}$ and \\ Rajneesh Narula ${ }^{5}$
}

\footnotetext{
${ }^{7}$ Fisher College, Ohio State University, Columbus, $\mathrm{OH}$, USA; ${ }^{2}$ Darla Moore School of Business, University of South Carolina, Columbia, USA; ${ }^{3}$ Universidad Austral, Buenos Aires, Argentina;

${ }^{4}$ Fox School of Business, Temple University, Philadelphia, PA, USA; ${ }^{5}$ Henley Business School, University of Reading, Reading, UK
}

\section{Correspondence:}

G McDermott, Darla Moore School of Business, University of South Carolina, Columbia, USA

e-mail: gerald.mcdermott@moore.sc.edu

\begin{abstract}
This article argues that innovation in and from emerging economies is largely shaped by the challenges of sustained catching-up with the advanced economies. Just as firms and industries are constantly seeking to upgrade their technological and organizational capabilities, so too are their societies reconfiguring their institutions and networks to improve their knowledge resources. Such a co-evolutionary process requires IB scholars to draw on interdisciplinary work from the innovation and development literature in order to reconsider the key drivers of innovation at multiple levels within these economies. Innovation is not just limited to technological activities but includes organizational and transactional improvements, and is largely a process of recombination of local and imported knowledge, shared through multiple forms of collaboration. This can redefine the FSAs of local and foreign firms, often shaped by the strategies of domestic public and private actors. Simultaneously, policymakers need to develop the appropriate institutions needed to underpin $R \& D$, training, standards, and knowledge coordination. MNEs play unique roles as instigators of innovation, as conduits for new knowledge, and as beneficiaries themselves, via their own recombination capabilities.
\end{abstract}

Journal of International Business Studies (2021) 52, 545-559.

https://doi.org/ | 0.1057/s41267-021-00426-1

Keywords: emerging economies; innovation; MNEs; economic development; FSAs; $\mathrm{R} \& \mathrm{D}$; recombination; alliances

\section{INTRODUCTION}

At the end of the twentieth century, most (if not all) industries were still dominated by firms from the advanced economies, broadly defined as North America, Western Europe, and Japan. Over the last two decades, we have witnessed fundamental changes in the structure of the global economy, not only in terms of the dynamics of multinational enterprise (MNE) expansion and global value chains (GVCs) but also in the significance of the emerging economies, and MNE activity to and from these countries. MNEs and local firm clusters from these economies have now risen to leading positions in many industries. Of course, not all of these changes are specific to emerging economies, but reflect pervasive
Received: 13 June 2020

Revised: 17 February 2021

Accepted: 7 March 2021

Online publication date: 20 April 2021 
trends attributed to globalization. These changes have largely been driven by the rapid liberalization of trade and investment, the concurrent expansion of MNEs, and the spread of GVCs. Although this growing cross-border interdependence has spurred a degree of technological, institutional, and economic convergence, there remains significant variation across nations in terms of firm capabilities, institutional configurations, and levels of development (Witt, 2019). This tension between convergence and variation offers scholars a unique opportunity to reassess core dynamics of innovation inside and outside of the firm.

This special issue focuses on emerging economies, which we define as those countries that have experienced, and are attempting to maintain, significant and sustained technological and economic catch-up with the advanced economies. We use the terms 'sustainable' and 'sustained' not in the sense implied by the UN Sustainable Development Goals, but to refer to growth and development that are not dependent upon natural resources or on volatile commodity prices, and where growth and development are not easily interrupted by the vagaries of markets, nor easily reversed. Indeed, catching-up and convergence have not been an inevitable consequence of market liberalization ${ }^{1}$. Rather, sustainable growth is fundamentally dependent on continuous upgrading and innovations, and such growth is a more holistic and complex phenomenon ${ }^{2}$ than growth through changes in factor prices. The definitive success stories of Japan, Korea, Singapore, Hong Kong, and Taiwan (to mention a few) in transitioning beyond 'emerging-ness' towards developed country status continues to inspire development and IB scholars and policymakers (Cuervo-Cazurra \& Genc, 2008).

We emphasize that not all developing countries are 'emerging'. While many countries have moved to higher GDP levels, they have not established the conditions for sustained growth. Achieving sustainable growth can be hindered by an overreliance on commodity exports, and a failure to develop adaptable innovation systems that respond to dynamic changes in competitiveness. Sustainable growth is also dependent on having stable functional governments with efficient state organs to implement policy through well-defined formal institutions; a healthy stock of private and public firms; and a threshold level of basic and advanced infrastructure.

Innovation by MNEs has been a critical component for sustained growth and competitive advantage for emerging economies. Research at the intersection of innovation studies, IB and development has pushed us to a better understanding of how innovation matters, and of its underlying processes and underpinnings. A key finding has been that the success or failure of economic and technological change requires a 'systems' view (Edquist, 1997; Lundvall, 1992). It is the efficacy and the extent of the linkages between a large variety of actors within an economy, and between actors in other economies (Hirschman, 1958; Lall, 1992), that shape sustainable growth and innovation.

We know that innovation increasingly depends upon collaborative activity by (domestic and foreign) firms, universities, and scientific establishments across borders, leading to growing crossborder knowledge flows (Bruneel et al., 2010). Although this varies considerably by sector, GVCs and MNEs link innovation systems in advanced market economies with those in emerging and developing economies, and economic integration between countries through multilateral and bilateral agreements can facilitate a diffusion of organizational and institutional forms (Liu \& Giroud, 2016). Emerging economies are especially rich terrains to assess the interaction between the innovative capabilities of MNEs and local firms. The insights from this special issue shape our reassessment in two key ways.

First, as GVCs and MNEs have deepened linkages and interdependencies between innovation systems in advanced market economies with those in emerging economies, new cross-border opportunities have led to novel challenges for both firms and countries. Firms cannot simply copy technologies or organizational models, but must recombine their resources and reinvent their internal capabilities, within the constraints of the innovation systems in which they are embedded. Innovation in emerging economies is driven largely by the process of firms overcoming significant technological and organizational gaps, as they seek first to enter, and later to advance up, the value chain, often hindered by their lack of absorptive capacities (Criscuolo \& Narula, 2008).

Second, the process is Schumpeterian in the sense that it incorporates both directional innovation as well as recombination. It is largely aimed at increasing value-added, and marked by the coevolution of different actors and analytical levels (Lamin \& Livanis, 2013). MNEs and local firms are neither interacting in a tabula rasa nor within a 
linear trajectory. The governments of host countries and domestic firms must adapt to gain access to new knowledge, while MNEs must alter their strategies and resources to both capture returns and protect their market positions (Cano-Kollmann et al., 2016)

Our analysis follows a recent trend by scholars to use emerging economies as terrains to explore core assumptions about FDI, foreign market entry, alliances, and institutions (Govindarajan \& Ramamurti, 2011; Henisz, 2000; Khanna \& Palepu, 2000; Morck et al., 2000; Narula, 2012). We also seek to build on work from fields such as strategy, organizational theory, economic geography, and economic sociology that have sought to identify the mechanisms that lead to different patterns of innovations, as well as the breakthrough and diffusion of new technologies and knowledge (Gordon \& McCann, 2005; Henderson \& Clark, 1990; Owen-Smith \& Powell, 2004; Rosenkopf \& Tushman, 1998). In doing so, we reflect on some of the key lessons, and map out some core trends for future research on innovation, both in general, and in the case of emerging economies in particular. The next section explores how the challenge of catching-up might offer new insights into the innovation process and into the attendant coevolution of firm and MNE capabilities, through the lens of IB theory. We then pull back and consider the role of the state and institutions in innovation. The paper then proceeds to bring these two perspectives together, first with new considerations about the development of firm-specific advantages (FSAs), and the critical role of recombination FSAs in the interaction of MNEs with local actors, and second, the cognitive factors shaping knowledge flows. Finally, we integrate these components in a brief review of the articles that compose this special issue, and offer some concluding remarks.

\section{INNOVATION IN EMERGING ECONOMIES: CATCH-UP, CO-EVOLUTION, AND THE CHALLENGE FOR MNES}

Innovation in emerging countries is surprisingly diverse. On the one hand, MNE innovation tends to reflect the types of activity associated with the level of the host economy's technological development, with research-intensive or more adaptive development activities being located where innovation systems optimally support these respective activities. There is also a somewhat predictable tendency for innovation activities by firms located in developing countries to mimic those undertaken by MNEs in more advanced economies. Indeed, to a great extent, until about 30 years ago, innovation by MNEs in developing countries was largely incremental and adaptive.

The last 30 years has resulted in rapid change. In emerging economies like India, MNEs now play a more critical role in developing innovations (Bhagavatula et al., 2019). Initially, MNE investments in these countries were regarded as cost-efficient locations for adaptive and incremental $R \& D$, but have evolved to full-blown research-intensive $R \& D$ centers, having moved up in terms of the quantity of their output as well as their value-added. This process has been called 'subsidiary evolution' (Cantwell \& Mudambi, 2005). At the same time, emerging economy firms have also been increasing the sophistication and output of truly high-tech innovations, particularly when they can exploit their local context.

On the other hand, innovations by emerging economy firms can potentially be truly disruptive, not only because widespread imitation can lead to genuine innovations but also because there is a path-breaking component of emerging countryspecific innovation. Some innovations are based on non-traditional replication and imitation, and such firms have been described as copycats (Shenkar, 2010). Firms may also indulge in reverse innovation (Govindarajan \& Ramamurti, 2011), where innovations are designed to save resources or capital and can be scaled-up and deployed elsewhere. Similarly, jugaad innovation emphasizes the propensity of some firms to improvise in order to deal with the institutional and resource constraints (Radjou et al., 2012).

Both the strategy and the IB literature over the last two decades have viewed innovation as a process of creating new combinations of knowledge and skills that require dynamic combinatory capabilities (Henderson \& Clark, 1990; Kogut \& Zander, 1992; Moran and Ghoshal, 1999). Such capabilities can come from experiments in organizational forms, ownership structures, especially using alliances, as well as network configurations (Foss, Foss, Klein \& Klein, 2007). The prevalent view is that MNEs create capabilities (firm-specific advantages) to integrate new knowledge and relationships from abroad with their existing routines and organizations (Kumaraswamy et al., 2012; Narula et al., 2019). This perspective is extremely salient when examining innovation in emerging economies, 
since MNEs function as crucial conduits to transfer knowledge across multiple contexts (Narula, 2014). Innovation in all its forms is a key aspect of maintaining and upgrading firm-specific advantages (FSAs), and the IB literature has long acknowledged that these innovations are not necessarily limited to technological assets but may include organizational, managerial, and transactional innovations (Narula et al., 2019). The IB literature, in engaging with innovation and development, has also long been concerned with how knowledge and skills that constitute FSAs are affected by locations, and how the portfolio of an MNE's assets are a function of its activities in various locations. That is, how both its own geographically distributed operations contribute to this portfolio and those of other non-affiliated actors located in proximity to them (Iammarino \& McCann, 2013; Narula \& Santangelo, 2012). There is a growing emphasis on the breadth of innovation beyond the narrow focus on the ownership of technological assets, and an inclusion of other key knowledge sets, including organizational skills and efficiencies associated with managing complex hierarchies and minimizing transaction costs between and within firms and markets (Andersson, Buckley \& Dellestrand, 2015; Buckley and Casson, 2009; Narula, 2019; Korosteleva, Estrin \& Mickiewicz, 2021).

More recently, the IB literature has emphasized FSAs associated with recombination (Verbeke, 2009; Lee, Narula \& Hilleman, 2021). Innovation as recombination at different levels is essential to the challenge of catching-up for emerging economies. New knowledge can be imported by MNEs as well as by local firms, and dispersed through GVCs. Firms continually develop FSAs, creating new products and processes to improve quality and valueadded to access and experiment incrementally with new combinations of material, human, and knowledge inputs (Giuliani, Pietrobelli and Rabellloti, 2005; Kumaraswamy et al., 2012). This perspective of innovation for catch-up as a learning process is often highlighted in discussions of the catch-up of East Asian tigers in the late twentieth century. Nelson (2008) noted how these catching-up countries offered a unique opportunity to understand the alternative paths of innovation and the interaction of knowledge resources inside and outside the firm. Internally, even those firms that merely wish to adopt new technologies are required to integrate them into what are often mis-aligned organizational capabilities (McDermott \& Pietrobelli, 2017). Externally, the systemic and institutional aspects of catch-up can be much more difficult, not only in terms of institutions, but also in the broader configuration of knowledge resources (Jackson \& Deeg, 2008; Lall, 1992). This special issue builds on this view by highlighting how the interplay of knowledge resources internal and external to the firm involve three levels of recombination.

First, recombination involves creating the FSAs to acquire knowledge and then adapting it for new uses and conditions (Carnabuci \& Operti, 2013; McDermott et al. 2009). It is a process of trying to combine local knowledge and resources with the foreign technology, practices and routines in order to create value, i.e., a "bundling" process (Hennart, 2009). This is a more incremental and continuous process, and requires firms (foreign and domestic) and ecosystems to interact in new ways.

Second, innovation in emerging economies often blurs the line between process and product innovation. The learning and eventual mastery associated with catch-up begins by breaking down intricate processes to ensure quality at ever-largerscale economies. The process of continuous improvement comes with constant adjustments to the production process as well as the product (Helfat \& Winter, 2011). Even the transfer of highly codified practices can demand quite localized applied knowledge to alter existing capabilities (Szulanski, 1996), all the more exacerbated in resource-constrained settings.

Third, MNEs act as conduits to integrate firmspecific and country-specific advantages (Kogut \& Zander, 1992; Narula \& Verbeke, 2015; Rugman, 1980). MNEs can and do break the national boundaries around the domestic "diamond", i.e., they operate as "diamond connectors" across the diamonds of multiple countries (Rugman \& D'Cruz, 1993). The conceptualization of networks, both within an MNE across locations and in local external partnerships, helps unpack this complex web of relationships. In this sense, the links between country-specific advantages and firmspecific advantages are reciprocal, and are complex in the implications for home and host countries. Consequently, the impact of FDI on the development of host emerging economies is also quite nuanced, and depends on the interactions between institutional- and firm-level factors (Narula \& Dunning, 2000; Narula \& Pineli, 2019). However, as noted in the literature on innovation systems, the relative success and paths of firms creating new absorptive capacities are greatly shaped by the 
systems and institutions in which they are embedded (Criscuolo \& Narula, 2008).

MNEs are both conduits of knowledge resources as well as focal points for the adaptation of these resources. This has important implications for the dynamics of innovation in emerging economies. As the MNE facilitates flows of technology, capital, and practices, it also learns how to reconcile its strategic aims and organizational approach with the often radically different and fluid landscape of host country organizations and institutions.

These lessons are equally relevant for outward FDI. Investments for the purposes of strategic assetseeking has been a hallmark of EMNEs, with the intention of benefiting from proximity to key external actors to take advantage of linkages and spillovers, as well as by engaging with customers, suppliers, and competitors (Luo \& Tung, 2007; Meyer, 2015).

In the next section, we discuss these challenges at different levels of analyses, while highlighting how local firms and MNEs confront the simultaneous challenges of value creation and appropriation along with the reconfiguration of host institutions and ecosystems.

\section{STATES, INSTITUTIONS, AND INNOVATION IN EMERGING ECONOMIES}

The emphasis in the IB literature on institutional voids, as well as the concept of "distance" between rules and norms of countries, often obscure the considerable organizational and institutional innovations occurring in emerging economies, and overlook how the catch-up challenge shapes the different ways in which public and private actors can reconfigure their innovative capacities (Mair et al., 2012; McDermott et al. 2009). To the extent that innovation in firms depends on their access to new knowledge and their learning processes via the relationships to other (domestic or foreign) firms and relevant state actors, emerging economies present some unique challenges and opportunities for scholars and practitioners alike. Work on comparative capitalism (Jackson \& Deeg, 2008) and state capitalism (Inoue et al., 2013) remind us how institutions and the state can create different paths of innovation. States vary in the configuration of their industrial support and corporate governance institutions, which in turn, greatly shape the competitive advantages of the embedded firms and the insertion or adaptation challenges of foreign firms (Jackson \& Deeg, 2008; Padgett \& Powell, 2012).

Indeed, institutions are a critical aspect of both the innovation systems and the IB literature (Cantwell et al., 2010; Castellani et al., 2013; Wu $\&$ Park, 2019). Institutions (in the Northian sense) play an inordinately large role in shaping competitiveness of a nation's industries (Peng et al., 2008). States shape knowledge flows through the imposition of formal institutions such as laws and regulations, although relationships between actors within an innovation system are governed just as much by informal institutions. This presents challenges for states in their pursuit of higher levels of innovatory activity, and the building-up of competitive advantage (Narula, 2002). The provision of public goods and infrastructure needed for efficient knowledge creation have to be complemented by the careful implementation of related policy dimensions. This shapes the capacity of MNEs to engage in R\&D collaboration, both inter-firm and with non-firms. States matter, not only as enforcers and creators of institutions but also as direct participants in innovation systems through public organizations, such as research institutes and universities, and as orchestrators of industrial and innovation policy (Laursen \& Santangelo, 2017; Mazzucato, 2016, 2018).

State intervention through institutions or through direct participation can facilitate skills development and knowledge creation programs or services. This may include public investments in $\mathrm{R} \& \mathrm{D}$ and new technologies that individual firms find too risky to undertake on their own, as well as the training in practices and standards 'imported' from advanced economies (Perez-Aleman, 2011; Pietrobelli \& Rabellotti, 2011). Such state intervention can encourage breaking the isolation of existing clusters and the creating of ties or working relationships with leading firms in nascent industries, channeling new knowledge into the community. In addition, they can expedite the development of social and knowledge bridges between different producer communities (McDermott et al., 2009). The state can, via governance rules and services, foster direct, collaborative learning relationships between firms (Breznitz, 2005; Narula \& Dunning, 1998).

The state's direct involvement in emerging economies extends to its direct role in the ownership and/or control of key firms and MNEs and their innovation strategies (Cuervo-Cazurra, 2017; Hoskisson et al., 2000; Meyer \& Peng, 2016). This is 
a common theme throughout the literature, especially in the context of China, about how different levels of state ownership affect the levels and patterns of R\&D investment in domestic firms and within collaborative ventures (Boeing et al., 2016; Liu \& Buck, 2007; Zhao et al., 2005). Different approaches to governance and managerial autonomy affect the variance in innovation strategies undertaken by these firms.

Political ties and state ownership are only one set of research avenues in understanding the impact of public and private actors on the innovative capacities of emerging economies. While policies linked to ownership requirements and technology transfer agreements may be a "stick" that states use to force the transfer of knowledge from MNEs to local firms, industrial policy may also use "carrots" in supporting learning and knowledge diffusion via the creation of new institutions and linkages. They often involve non-market organizations, such as universities and public-private $R \& D$, as well as training centers and trade associations. These can enhance technological change and the implementation of new practices (McDermott et al., 2009; McEvily \& Zaheer, 1999).

The involvement of the state has been crucial for many of the successful emerging economies, but it is far from obvious what is the optimal level of government intervention. The development literature is replete with examples of questionable policies for creating new state agencies or using economic incentives to induce cluster creation (IDB, 2014; OECD-ECLAC, 2013; UNCTAD, 2013). State agencies and private firms by themselves may not have sufficient resources and knowledge to solve the problems of innovation capacities in emerging economies, because purely public or purely private solutions may be disconnected from key actors. Hence, new development partnerships are more likely to have success when they are public-private in governance, mission, and membership (Mair et al., 2012; McDermott et al., 2009). While public-private partnerships may facilitate knowledge flows and responsiveness, it also makes firms, especially foreign MNEs, very cautious about how much they are willing to share with their partners.

The difficulties of finding an optimal path for state involvement is apparent in the article by Parente, Melo, Andrew, Kumaraswamy and Vasconcelos (2021) in this issue. They demonstrate that the public agro-research institution in Brazil, Embapra, began to play a more constructive role in facilitating knowledge diffusion and learning for local firms only when it accelerated collaboration in research with more advanced domestic and foreign firms. Similar to the work on bio-sciences in the US (Powell, White, Koput \& Owen-Smith, 2005), this policy shift not only changed the network structure of the industry but also created new concerns about property rights and patent protection. Similar issues have been raised in contexts like China and India (Brandl et al., 2019; Doh et al., 2004; Zhao, 2006). Indeed, Lazzarini, Mesquita, Monteiro and Musacchio (2021) in this issue reveal how foreign and domestic firms adjust their levels of $R \& D$ investment and patterns of innovation rates as the ownership and collaboration requirements change over time.

\section{RECOMBINING AND UPGRADING FSAS WITHIN INNOVATION SYSTEMS}

Private and public firms (both domestic and foreign) are at the heart of any innovation system. Innovation hinges on both local firms and foreign MNEs accessing knowledge and learning from one another, a well-acknowledged aspect in both the IB and innovation literature (Audretsch \& Feldman, 1996; Jindra et al., 2009; Santamaría et al., 2009; Un $\&$ Rodríguez, 2018). The configurational view is crucial, because the capacity of firms to optimize learning depends on government policies that shape formal institutions. Institutions can enable or hinder the learning process for both domestic and foreign firms. Societies create a plethora of organizations to support industrial development and firm growth, but closer study of innovation in emerging economies can help discern just which types of institutions and policies matter most. Governments and industry may pour resources into universities, $R \& D$ institutes, training centers, and the like, but largesse per se does not necessarily breed value creation and efficiency (e.g., Broström et al., 2009; Dornbusch \& Neuhäusler, 2015).

Although countries such as South Korea and China have relied on large conglomerates as an explicit tool for growth, others such as Taiwan have not done so. We believe that to emphasize specific types of firms as being a precondition for sustained growth is a common error. Understanding innovation requires an acknowledgment of the interdependencies between large domestic firms (both state and private), foreign MNEs, and domestic small- and medium-sized enterprises (SMEs) (IDB, 2014; McDermott \& Pietrobelli, 2017). Each of 
these sets of firms confront the challenge of accessing new knowledge and recombination in different ways. In general, they aim to overcome the technology gap by creating capabilities to explore new market opportunities. In order to link into new flows of knowledge, they need to restructure their existing practices and upgrade their absorptive capacities in response to new technologies and standards (Perez-Aleman, 2010; Zhao \& Anand, 2013). In more knowledge-intensive sectors, local firms and their governments put in place mechanisms for continuous knowledge flows and recombination. This creates significant opportunities to rethink the roles and strategies of both large domestic and foreign firms, as well as those of smaller firms in GVCs.

All modern economies have relied on global flows of knowledge, and to varying degrees on a direct engagement with international markets and firms through MNEs. Local firms with the necessary absorptive capacity have been able to adjust their optimal balance of asset exploitation and asset augmentation through interacting with global actors. From an asset-augmentation/asset-seeking perspective, having a breadth of experience and ideas increases the firm's capabilities while also introducing possible new ideas for recombination (Verbeke, 2009). From an asset-exploitation perspective, having additional markets allows firms to utilize their knowledge and operational abilities to a fuller extent (Buckley \& Casson, 2009). Coordinating with partners internationally also allows (domestic) firms to increase their absorptive capacity. Through learning and strong relational ties, MNEs are able to increase their current knowledge stock as well as the potential for future knowledge flows (Hamel, 1991; Kale \& Anand, 2006). While the historical focus of knowledge transfer has been from the developed world to the developing world, the mainstream IB literature recognizes the potential for MNEs to learn from subsidiaries located in developing and emerging countries (Berry, 2014; Birkinshaw \& Hood, 1998; Cantwell \& Mudambi, 2005; d'Agostino et al., 2013; Narula, 2014).

One of the key weaknesses of IB scholarship is that it has paid minimal attention to the role of SMEs in both innovation and development (Giuliani et al., 2005; Kumaraswamy et al., 2012; McDermott \& Pietrobelli, 2017). SMEs are important in multiple ways. First, SMEs in emerging economies are important as potential suppliers/partners within GVCs. Second, they play a crucial role as innovators. Third, they reflect the effectiveness of the domestic milieu for entrepreneurship. Indeed, SMEs represent the vast majority of firms in almost every economy, and the health of an economy and the efficiency of its institutions is reflected in the opportunities for SMEs to thrive. The analysis of innovation in emerging economies allows us to consider how SMEs approach innovation, entrepreneurship, and capability creation (Mariotti \& Piscitello, 2001; Radas \& Bozic, 2009). SMEs face an even greater deficit in financial resources, knowledge, and capabilities than larger firms, but, at the same time, their smaller size makes them more flexible. They are also much more efficient in leveraging opportunities to collaborate in innovation than their larger counterparts, and, it may be argued, have benefited much more from the trend towards open innovation (Narula, 2004; Van de Vrande et al., 2009).

The IB literature is equivocal that the building-up of FSAs and the creation of competitive advantage depends crucially on the ability of firms to 'bundle' or 'recombine' a diversity of different asset classes (Lee et al., 2021; Narula et al, 2019). Not all of these assets are within the boundaries of the MNE. Some of these FSAs are owned and controlled by other firms, while others may be location-bound, and associated with the specific innovation systems (Narula \& Verbeke, 2015). These "recombination FSAs", critical to the MNE, are akin to the orchestration capabilities described by Teece (Lee et al., 2021; Pitelis \& Teece, 2018).

Recombination FSAs are especially critical for developing and operating GVCs. Learning how to identify the most cost-efficient and strategically optimal way to divide and coordinate geographically and organizationally dispersed activities is not easily acquired (Kano, 2018). Coordinating GVCs offers many challenges. The lead firms in MNE-led GVCs can be instrumental in demonstrating what is required in terms of product specifications or quality control. However, efficiently managing MNE-led GVCs is no simple task, as they are less likely to be able to guide suppliers on how to implement these capabilities within GVCs that consist of arms-length suppliers (Corredoira \& McDermott, 2014; Perez-Aleman, 2011). There are difficulties in transferring apparently well-codified production processes, largely because of misunderstood assumptions about existing routines, skills, and resources in the local context. 


\section{COGNITIVE AND STRUCTURAL CONSTRAINTS TO KNOWLEDGE FLOWS}

Inter- and intra-firm knowledge flows are critical in understanding the dynamics between the MNEs and local firms in emerging economies. This is especially relevant in the case of GVCs, where suppliers may also be competitors, or have the potential to become competitors. MNEs balance the gains from helping other firms to upgrade their capabilities with the risks of losing their own competitive advantages. A "teaching-learning" lens to understand these flows is particularly relevant when these flows are voluntary and intentional (Zhao et al., 2005). Recognizing both intentional knowledge flows and leakages allows us to look beyond issues of willingness to share knowledge as well as potential opportunism, and to identify optimal strategies for knowledge transfers (Chen et al., 2016; McCann \& Mudambi, 2005).

Intentional knowledge flows between local and foreign firms are by no means limited to customersupplier relationships, equity-based joint ventures, or intra-MNE hierarchies, as the considerable literature on alliances demonstrates (Almeida et al., 2002; Castellani \& Zanfei, 2002, 2004; Hagedoorn, 1993; Martinez-Noya \& Narula, 2018). Ideally, strategic alliances can perform two contrasting roles simultaneously: they can help to limit unintentional knowledge flows between partners, while also creating a systematic channel for knowledge exchange (García-Canal et al., 2018; Narula \& Santangelo, 2009). However, international R\&D alliances tend to have a high failure rate, despite their considerable potential as a mechanism for catching-up (Reuer \& Zollo, 2005; Zhao et al., 2005). In deciding to collaborate for the purposes of $\mathrm{R} \& \mathrm{D}$, firms must not only consider their own cognition and structure but also that of potential partners (Bureth et al., 1997; Santangelo, 2000). The choice of partners will be dependent on the potential partner's structure and cognitive choices, as well as the interaction between the firms. These choices also create path dependence, as the partner firms co-develop inter-unit connectivity, mirroring, and coordination mechanisms via shared routines over time (Kim \& Anand, 2018; Zollo \& Winter, 2002). Therefore, when MNEs and local firms engage with each other, absorptive capacity is not limited to their existing cognition and structures but also to the complex interconnectedness that arises within the entire ecosystem because of their collaboration (Zhao \& Anand, 2013).

The ability of local firms to benefit from either intentional or unintentional knowledge flows is a function of their absorptive capacities (Rojec \& Knell, 2018). When developing and maintaining firm-level absorptive capacity in an international context, firms have to deal with cognitive tradeoffs. They must consider 'latitudinal' and 'longitudinal' absorptive capacity constraints (Vasudeva \& Anand, 2011). Firms can increase their 'latitudinal' absorptive capacity by balancing multiple existing technologies in a new domain. Alternatively, firms can increase their 'longitudinal' absorptive capacity, by exploring new technologies that were previously unknown to them. The choice is, in part, endogenous to the firm as it decides where to invest, and with whom to interact (Alcacer \& Chung, 2007; Helfat, 1994). States and policymakers, especially in emerging countries, also play a significant role in shaping the absorptive capacity of firms. They are able to shape knowledge flows directly through formal institutions that may require or restrict intentional knowledge flows, for instance, by prescribing local content rules or by explicitly requiring domestic licensing from MNEs to local firms (Javorcik \& Spatareanu, 2008).

Ownership restrictions matter: many emerging economies define the governance structures of MNE subsidiaries, in particular placing emphasis on the shape and structure of joint ventures, and the participation of local state-owned enterprises within GVCs. As the articles in this special issue explore in different ways, these restrictions directly affect the abilities of local firms and MNEs to recognize, assimilate, and apply knowledge. States can limit MNEs' access to certain aspects of the national innovation system, or key inputs (including labor), thus diminishing both the MNE and local firms' ability to assimilate knowledge and innovations. The state can impede the MNE from directly engaging in certain industries, or specific aspects of the value chain, thereby reducing the MNE's capacity to fully leverage its FSAs. Through failing to enact or by enforcing strong intellectual property rights (IPRs), states can affect spillovers from MNEs (Berry, 2017). Contractual and political hazards can also affect the MNEs' decision-making processes (Henisz \& Williamson, 1999), their partnering strategies (Santangelo et al., 2016), and where they decide to locate key innovation activities within the MNE organization. 
The development of recombination FSAs is also shaped by inter-unit, intra-MNE relationships as they define the degree to which a firm transmits knowledge to a subsidiary (Van Wijk et al., 2008). Firms have three levers when it comes to structuring information flows: inter-unit connectivity between the source and recipient organizations, the extent of mirroring, and the coordination mechanisms (Kim \& Anand, 2018). Firms can adjust their inter-unit connectivity through having a strong collaboration network that assists interunit transfers (Carnabuci \& Operti, 2013; Schotter et al., 2017). The extent to which firms can engage in mirroring depends on several factors, which include the host-country's IPR protections, their own internalization effects, and the complexity of technical knowledge when making mirroring decisions (Ivus et al., 2017). Finally, coordination mechanisms will also affect a firm's innovation choices, dependent on the types of interdependencies between the firm's subunits (Andersson et al., 2015), as well as its information-processing capabilities (Tushman \& Nadler, 1978).

\section{PUSHING FORWARD}

Innovation to and from emerging economies is a fertile research terrain for international business scholars with fundamental implications for managers and policymakers alike. Our extant knowledge indicates that this phenomenon is a systemic outcome of an entire innovation milieu, and one which requires recognition of interdependencies between different levels of analyses (national, subnational, organizational, individual). We also recognize that both firms and countries are heterogeneous and path-dependent, such that each follows an idiosyncratic path in its evolution. Yet, there are commonalities in the ways in which the ecosystem of institutions, governments, and networks interact with domestic firms and MNEs.

The paper by Lazzarini et al., (2021) examines the relative merits of state ownership (state-owned enterprises, SOEs) and private ownership (privately-owned enterprises, POEs) on firm invention output in both emerging and developed countries. Their dataset allows the authors to analyze how certain institutional governance traits interact with different ownership arrangement. They track the frequency and impact of patent inventions over many years, and across many countries and industries. Somewhat counter-intuitively, they find that, in some circumstances, SOEs outperform POEs in certain types of invention output. However, the advantage of SOEs declines with the degree of political intervention, because such intervention reduces managerial autonomy.

The paper by Sun, Deng and Wright (2021) pursues the issues of the politics of innovation further by examining the risks and benefits for MNEs entering international joint ventures (IJVs) with state-owned enterprises. States often attempt to boost domestic R\&D and technology acquisition by coercing MNEs into IJVs, but it is unclear what sustained gains come to the relevant firms or country. China has been at the forefront of creating policies to induce such investments, and in examining IJVs in China, this paper highlights the different dimensions of the entanglements between SOEs versus POEs. On the one hand, they find that, despite concerns of government appropriation and weak IPRs, IJVs with SOEs have greater R\&D investment relative to IJVs with POEs. These results are mitigated by issues of relative power, foreign technology transfers, and the level of political intervention. On the other hand, IJVs with SOEs have fewer innovation outputs than IJVs with POEs. While states can induce greater investments and technological transfers through ownership restrictions, they have relatively more problems with reaping the gains.

The paper by Genin, Tan and Song (2021) helps us to improve our understanding of state governance and firm innovation. As an example, the authors uses the Chinese SOEs in high-speed rail, a context that is unique in some respects, but nonetheless allows us to consider the relevance of state governance and market mechanisms for firm innovation. They put together thought-provoking arguments on how institutional forces, governance practices, and firms' restructuring efforts help to explain innovation performance. The authors also provide some speculative prescriptions for emerging economy firms in other contexts.

The paper by Parente et al. (2021) is a unique examination of the process by which public institutions can help or hinder the scope and scale of firm-level innovation, with a focus on SMEs. They undertake an ethnographic study of the Brazilian soy industry and analyze the role of Embrapa, a world-renowned agricultural research and extension institution, in the transformation of innovation rates and productivity. In so doing, their analysis allows us to see how natural resourcedependent economies can create greater valueadded for world markets. Their novel contribution 
lies in going beyond process efficiencies by highlighting the potential of complex product innovation. The article reveals how Embrapa helps to accelerate and broaden the benefits of innovation in seeds by both blurring the public-private boundaries and improving governance. The authors document that this enhanced knowledge creation and diffusion occurs via a complex network of collaboration with large firms (often foreign MNEs) and small farmers.

The paper by Gregorič, Rabbiosi and Santangelo (2021) is an interesting perspective on the signaling value of global diaspora membership. The authors, drawing on signaling theory, hypothesize that ownership by members of the global diaspora constitutes a reliable third-party signal of emerging economy firms' trustworthiness. In turn, this enhances the firms' potential for international technology licensing. This finding allows us to understand the nature of the liability of origin for emerging economy firms, particularly in technology-oriented industries. Such a liability of origin may be due to the weak institutions in many emerging economies. The research represents an exemplar of connecting the dots among the national-/institutional-, sub-national-, and firmand individual- levels to shed light on the very pertinent issue of global diasporas and the international migration that seeds and replenishes them (Barnard et al., 2019).

\section{CONCLUDING REMARKS}

The term 'emerging' has become an imprecise adjective to describe all countries and economies that are not 'advanced' or 'developed', which themselves are imprecise euphemisms. We are more precise in our definition that emerging countries are those that possess specific characteristics. Emerging countries are not only middleincome countries but also those that demonstrate system-wide evidence and the capacity to engage in sustained catch-up, growth, and development, built upon having stable functional governments that are able to implement policies through well-defined formal institutions, a vigorous stock of private and public firms, and a threshold level of basic and advanced infrastructure.

For most developing (non-emerging) countries, achieving the economic and socio-political milieu, and the innovation system of an emerging economy, is an aspiration; for the handful of emerging economies that have sustained this position over time, the desire to move beyond 'emerging-ness' in the longer term is tempered by the challenge of simply maintaining the status quo. It is by now the conventional wisdom that, in an interdependent global economy linked through trade and investment, both firms and policymakers need to sustain the capacity to innovate. Yet, innovation policies and strategies cannot remain static and universal: they vary not only by firms (which are heterogonous) and industry (requiring different inputs and markets) but also by country (which are each differently endowed). The innovation strategies of MNEs that are 'leaders' in a given industry will differ from those that are followers, with different resources and capabilities commensurately determining how they will innovate, and with whom they can collaborate. Likewise, the kinds of innovation undertaken by the lower-tier suppliers within a given GVC with a predominantly local footprint will differ from those with a multinational presence.

This article has argued that these differences and dynamics in the context of emerging countries are shaped largely by the challenge of catching-up and by a co-evolution of firm capabilities and institutional capacities. Catching-up is often a slow process of recombination of local and imported knowledge for both local firms and MNEs, in which process and product innovations are blurred. Catching-up also means that countries need to constantly reconfigure their institutions to induce, coordinate, and upgrade the FSAs of domestic firms to successfully engage with GVCs and MNEs. This context highlights the unique position of MNEs as a channel for new standards, knowledge, and resources, as it attempts to benefit from value creation in host countries, inside and outside its own boundaries. However, in doing so, the MNE can fortify its own FSAs by adapting itself to collaborate with local firms and also impact the ongoing institutional reconfiguration in which it finds itself.

Policymakers are not always aware of these multilevel dynamics, and are rarely familiar with industry-specific nuances: as firms and industries move closer to the technological frontier (especially in more knowledge-intensive sectors), they require different institutions, support, and policy support than those still at more simple value-adding activities (or in more mature, resource-intensive sectors). These issues are complicated by sociopolitical considerations, colored by the presence of economic, social, and political interest groups, 
and of constraints due to structural path dependence. These issues can result in lock-in and inertia in countries and industries at any stage of development (Narula, 2002; Figueiredo \& Piana, 2018; Herstad, Bloch, Ebersberger \& Van De Velde, 2010; $\mathrm{Fu}, 2015)$. Thus, the so-called 'middle-income trap' remains a vague concept, because it is difficult to distinguish between resilience and negative lock-in, or between sunset sectors and sunrise industries. Connecting the actions and capabilities of firms and MNEs to the more macro-level issues of industrial and structural change remains a nascent field of study, and requires more interdisciplinary thinking (Pineli et al., 2021). Indeed, if anything, this special issue illustrates the importance of multidisciplinary thought, and the need for more explicit cross-fertilization between innovation studies, development, and international business.

\section{ACKNOWLEDGEMENTS}

Comments from Davide Castellani, Grazia Santangelo, jill Juergensen, Saul Estrin, and three anonymous

\section{REFERENCES}

Alcacer, J., \& Chung, W. 2007. Location strategies and knowledge spillovers. Management Science, 53(5): 760-776.

Almeida, P., Song, J., \& Grant, R. M. 2002. Are firms superior to alliances and markets? An empirical test of cross-border knowledge building. Organization Science, 13(2): 147-161.

Anand, J., \& Kogut, B. 1997. Technological capabilities of countries, firm rivalry and foreign direct investment. Journal of International Business Studies, 28: 445-465.

Andersson, U., Gaur, A., Mudambi, R., \& Persson, M. 2015. Unpacking inter-unit knowledge transfer in multinational enterprises. Global Strategy Journal, 5(3): 241-255.

Audretsch, D. B., \& Feldman, M. P. 1996. R\&D spillovers and the geography of innovation and production. The American Economic Review, 86(3): 630-640.

Barnard, H., Deeds, D., Mudambi, R., \& Vaaler, P. 2019. Migrants, migration policies, and international business research: Current trends and new directions. Journal of International Business Policy, 2(4): 275-288.

Berry, H. 2014. Global integration and innovation: Multicountry knowledge generation within MNEs. Strategic Management Journal, 35(6): 869-890.

Berry, H. 2017. Managing valuable knowledge in weak IP protection countries. Journal of International Business Studies, 48(7): 787-807.

Beugelsdijk, S., \& Mudambi, R. 2013. MNEs as border-crossing multi-location enterprises: The role of discontinuities in geographic space. Journal of International Business Studies, 44(5): 413-426.

Bhagavatula, S., Mudambi, R., \& Murmann, J. P. 2019. Innovation and entrepreneurship in India: An overview. Management and Organization Review, 15(3): 467-493.

Birkinshaw, J., \& Hood, N. 1998. Multinational subsidiary evolution: Capability and charter change in foreign-owned subsidiary companies. Academy of Management Review, 23(4): 773-795. reviewers have been invaluable in improving earlier drafts of this paper.

\section{NOTES}

${ }^{1}$ Indeed, the evidence would suggest that there has been rising inequality, both within countries and between countries. For a review, and a discussion of the role of MNEs in inequality, see Narula and van der Straaten (2021).

${ }^{2} \mathrm{~A}$ large literature has arisen to explain the failure of a number of countries to catch-up, including a nascent (and somewhat controversial) literature on the 'middle-income trap' (Felipe, Kumar \& Galope, 2017; Gill \& Kharas, 2007; Doner \& Schneider, 2016). The same 'failure to launch' has also been attributed to the 'natural resource curse', which is also controversial (for a discussion, see Shapiro, Hobdari, Peng \& Oh, 2018). A third controversial explanation has been the Lewisian turning point (Gollin, 2014).

Boeing, P., Mueller, E., \& Sandner, P. 2016. China's R\&D explosion-Analyzing productivity effects across ownership types and over time. Research Policy, 45(1): 159-176.

Brandl, K., Darendeli, I., \& Mudambi, R. 2019. Foreign actors and intellectual property protection regulations in developing countries. Journal of International Business Studies, 50(5): 826-846.

Breznitz, D. 2005. Collaborative public space in a national innovation system: A case study of the Israeli military's impact on the software industry. Industry and Innovation, 12(1): 31-64.

Broström, A., McKelvey, M., \& Sandström, C. 2009. Investing in localized relationships with universities: What are the benefits for R\&D subsidiaries of multinational enterprises? Industry and Innovation, 16(1): 59-78.

Bruneel, J., d'Este, P., \& Salter, A. 2010. Investigating the factors that diminish the barriers to university-industry collaboration. Research Policy, 39(7): 858-868.

Buckley, P. J., \& Casson, M. C. 2009. The internalisation theory of the multinational enterprise: A review of the progress of a research agenda after 30 years. Journal of International Business Studies, 40(9): 1563-1580.

Bureth, A., Wolff, S., \& Zanfei, A. 1997. The two faces of learning by cooperating: the evolution and stability of interfirm agreements in the European electronics industry. Journal of Economic Behavior \& Organization, 32(4): 519-537.

Cano-Kollmann, M., Cantwell, J., Hannigan, T. J., Mudambi, R., \& Song, J. 2016. Knowledge connectivity: An agenda for innovation research in international business. Journal of International Business Studies, 47(3): 255-262.

Cantwell, J., \& Mudambi, R. 2005. MNE competence-creating subsidiary mandates. Strategic Management Journal, 26(12): 1109-1128.

Cantwell, J., Dunning, J. H., \& Lundan, S. M. 2010. An evolutionary approach to understanding international 
business activity: The co-evolution of MNEs and the institutional environment. Journal of International Business Studies, 41(4): 567-586.

Carnabuci, G., \& Operti, E. 2013. Where do firms' recombinant capabilities come from? Intraorganizational networks, knowledge, and firms' ability to innovate through technological recombination. Strategic Management Journal, 34(13): 1591-1613.

Castellani, D., \& Zanfei, A. 2002. Multinational experience and the creation of linkages with local firms: Evidence from the electronics industry. Cambridge Journal of Economics, 26(1): $1-25$.

Castellani, D., \& Zanfei, A. 2004. Choosing international linkage strategies in the electronics industry: The role of multinational experience. Journal of Economic Behavior and Organization, 53(4): 447-475.

Castellani, D., Jimenez, A., \& Zanfei, A. 2013. How remote are R\&D labs? Distance factors and international innovative activities. Journal of International Business Studies, 44(7): 649-675.

Chen, Y., Vanhaverbeke, W., \& Du, J. 2016. The interaction between internal R\&D and different types of external knowledge sourcing: An empirical study of Chinese innovative firms. $R \& D$ Management, 46(S3): 1006-1023.

Cohen, W. M., \& Levinthal, D. A. 1990. Absorptive capacity: A new perspective on learning and innovation. Administrative Science Quarterly, 35(1): 128-152.

Corredoira, R. A., \& McDermott, G. A. 2014. Adaptation, bridging and firm upgrading: How non-market institutions and MNEs facilitate knowledge recombination in emerging markets. Journal of International Business Studies, 45(6): 699-722.

Criscuolo, P., \& Narula, R. 2008. A novel approach to national technological accumulation and absorptive capacity: Aggregating Cohen and Levinthal. European Journal of Development Research, 20(1): 56-73.

Cuervo-Cazurra, A. (Ed). 2017. State-owned multinationals: Governments in global business. Springer.

Cuervo-Cazurra, A., \& Genc, M. 2008. Transforming disadvantages into advantages: Developing-country MNEs in the least developed countries. Journal of International Business Studies, 39(6): 957-979.

d'Agostino, L. M., Laursen, K., \& Santangelo, G. D. 2013. The impact of R\&D offshoring on the home knowledge production of OECD investing regions. Journal of Economic Geography, 13(1): 145-175.

Doh, J., Teegen, H., \& Mudambi, R. 2004. Balancing private and state ownership in emerging markets' telecommunications infrastructure: Country, industry and firm influences. Journal of International Business Studies, 35(3): 233-250.

Doner, R. F., \& Schneider, B. R. 2016. The middle-income trap more politics than economics. World Politics, 68(4): 608-644.

Dornbusch, F., \& Neuhäusler, P. 2015. Composition of inventor teams and technological progress-The role of collaboration between academia and industry. Research Policy, 44(7): 1360-1375.

Edquist, C. 1997. Systems of innovation: technologies, institutions, and organizations. London: Psychology Press.

Felipe, J., Kumar, U., \& Galope, R. 2017. Middle-income transitions: Trap or myth? Journal of the Asia Pacific Economy, 22(3): 429-453.

Figueiredo, P. N., \& Piana, J. 2018. Innovative capability building and learning linkages in knowledge-intensive service SMEs in Brazil's mining industry. Resources Policy, 58: 21-33.

Fleming, L. 2011. Recombinant uncertainty in technological search. Management Science, 47(1): 117-132.

Foss, K., Foss, N., Klein, P., \& Klein, S. 2007. The entrepreneurial organization of heterogeneous capital. Journal of Management Studies, 44(7): 1165-1186.

Fu, X. 2015. China's path to innovation. Cambridge: Cambridge University Press.
García-Canal, E., Guillén, M. F., Fernández, P., \& Puig, N. 2018. Imprinting and early exposure to developed international markets: The case of the new multinationals. BRQ Business Research Quarterly, 21(3): 141-152.

Genin, A., Tan, J., \& Song, J. 2021. State governance and technological innovation in emerging economies: Stateowned enterprise restructuration and institutional logic dissonance in China's high-speed train sector. Journal of International Business Studies. https://doi.org/10.1057/s41267-02000342-w.

Gerschenkron, A. 1962. Economic backwardness in historical perspective. Cambridge: Bellknap Press of the Harvard University Press.

Gill, I. S., \& Kharas, H. (eds.) 2007. An East Asian Renaissance: Ideas for economic growth. The World Bank.

Giuliani, E., Pietrobelli, C., \& Rabellotti, R. 2005. Upgrading in global value chains: Lessons from Latin American clusters. World Development, 33(4): 549-573.

Ghemawat, P. 2007. Why the world isn't flat. In Foreign policy: 54-60.

Gollin, D. 2014. The Lewis model: A 60-year retrospective. The Journal of Economic Perspectives, 283: 71-88.

Gordon, I. R., \& McCann, P. 2005. Innovation, agglomeration, and regional development. Journal of Economic Geography, 5(5): 523-543.

Govindarajan, V., \& Ramamurti, R. 2011. Reverse innovation, emerging markets, and global strategy. Global Strategy lournal, 1: 191-205.

Gregorič, A., Rabbiosi, L., \& Santangelo, G. D. 2021. Diaspora ownership and international technology licensing by emerging market firms. Journal of International Business Studies. https://doi.org/10.1057/s41267-020-00324-y.

Hagedoorn, J. 1993. Understanding the rationale of strategic technology partnering: Interorganizational modes of cooperation and sectoral differences. Strategic Management Journal, 14(5): 371-385.

Hamel, G. 1991. Competition for competence and interpartner learning within international strategic alliances. Strategic Management Journal, 12(S1): 83-103.

Helfat, C. E. 1994. Evolutionary trajectories in petroleum firm R\&D. Management Science, 40(12): 1720-1747.

Helfat, C. E., \& Winter, S. G. 2011. Untangling dynamic and operational capabilities: Strategy for the (n)ever-changing world. Strategic Management Journal, 32: 1243-1250.

Henderson, R., \& Clark, K. 1990. Architectural innovation: The reconfiguration of existing product technologies and the failure of established firms. Administrative Science Quarterly, 35(1): 9-30

Henisz, W. J., \& Williamson, O. E. 1999. Comparative economic organization-Within and between countries. Business and Politics, 1(3): 261-277.

Henisz, W. J. 2000. The institutional environment for multinational investment. The Journal of Law, Economics, and Organization, 16(2): 334-364.

Hennart, J.-F. 2009. Down with MNE-centric theories! Market entry and expansion as the bundling of MNE and local assets. Journal of International Business Studies, 40(9): 1432-1454.

Herstad, S. J., Bloch, C., Ebersberger, B., \& Van De Velde, E. 2010. National innovation policy and global open innovation: Exploring balances, tradeoffs and complementarities. Science and Public Policy, 37(2): 113-124.

Hirschman, A. O. 1958. The strategy of economic development. New Haven: Yale University Press.

Hoskisson, R. E., Eden, L., Lau, C. M., \& Wright, M. 2000. Strategy in emerging economies. Academy of Management Journal, 43(3): 249-267.

lammarino, S., \& McCann, P. 2013. Multinationals and economic geography: Location, technology and innovation. Cheltenham: Edward Elgar Publishing.

IDB 2014. Going global: Promoting the internationalization of small and midsize enterprises in Latin America and the 
Caribbean. Washington, D.C.: Inter-American Development Bank.

Inoue, C., Lazzarini, S., \& Musacchio, A. 2013. Leviathan as minority shareholder: Firm level implications of state equity purchases. Academy of Management Journal, 56(6): 1775-1801.

Ivus, O., Park, W. G., \& Saggi, K. 2017. Patent protection and the composition of multinational activity: Evidence from US multinational firms. Journal of International Business Studies, 48(7): 808-836.

Jackson, G., \& Deeg, R. 2008. Comparing capitalisms: Understanding institutional diversity and its implications for international business. Journal of International Business Studies, 39(4): 540-561.

Jindra, B., Giroud, A., \& Scott-Kennel, J. 2009. Subsidiary roles, vertical linkages and economic development: Lessons from transition economies. Journal of World Business, 44(2): 167-179.

Javorcik, B. S., \& Spatareanu, M. 2008. To share or not to share: Does local participation matter for spillovers from foreign direct investment? Journal of Development Economics, 85(1-2): 194-217.

Kale, P., \& Anand, J. 2006. The decline of emerging economy joint ventures: The case of India. California Management Review, 48(3): 62-76.

Kano, L. 2018. Global value chain governance: A relational perspective. Journal of International Business Studies, 49(6): 684-705.

Khanna, T., \& Palepu, K. 2000. The future of business groups in emerging markets: Long-run evidence from Chile. Academy of Management Journal, 43(3): 268-285.

Kim, S., \& Anand, J. 2018. Knowledge complexity and the performance of inter-unit knowledge replication structures. Strategic Management Journal, 39(7): 1959-1989.

Kim, J. K., \& Mudambi, R. 2020. An ecosystem-based analysis of design innovation infringements: South Korea and China in the global tire industry. Journal of International Business Policy, 3: 38-57.

Kogut, B., \& Chang, S. 1991. Technological capabilities and Japanese foreign direct investment in the United States. The Review of Economics and Statistics, 73(3): 401-413.

Kogut, B., \& Zander, U. 1992. Knowledge of the firm, combinative capabilities, and the replication of technology. Organization Science, 3(3): 383-397.

Korosteleva, J., Estrin, S., \& Mickiewicz, T. 2021. Schumpeterian entry: innovation, exporting, and growth aspirations of entrepreneurs. Entrepreneurship: Theory and Practice, forthcoming.

Kumaraswamy, A., Mudambi, R., Saranga, H., \& Tripathy, A. 2012. Catch-up strategies in the Indian auto components industry: Domestic firms' responses to market liberalization. Journal of International Business Studies, 43: 368-395.

Lall, S. 1992. Technological capabilities and industrialization. World Development, 20(2): 165-186.

Lamin, A., \& Livanis, G. 2013. Agglomeration, catch-up and the liability of foreignness in emerging economies. Journal of International Business Studies, 44(6): 579-606.

Laursen, K., \& Santangelo, G. D. 2017. The role of "noneconomic" endowments: Introduction to the special section on what we know and what we should know about international knowledge sourcing. Industrial and Corporate Change, 26(2): 279-284

Lazzarini, S. G., Mesquita, L. F., Monteiro, F., \& Musacchio, A. 2021. Leviathan as an inventor: An extended agency model of state-owned versus private firm invention in emerging and developed economies. Journal of International Business Studies. https://doi.org/10.1057/s41267-020-00327-9.

Lee, J. M., Narula, R., \& Hillemann, J. 2021. Unraveling asset recombination through the lens of firm-specific advantages: $A$ dynamic capabilities perspective. Journal of World Business, 56(2): 101193.
Liu, X., \& Buck, T. 2007. Innovation performance and channels for international technology spillovers: Evidence from Chinese high-tech industries. Research Policy, 36(3): 355-366.

Liu, X., \& Giroud, A. 2016. International knowledge flows in the context of emerging-economy MNEs and increasing global mobility. International Business Review, 25(1): 125-129.

Lorenzen, M., Mudambi, R., \& Schotter, A. 2020. International connectedness and local disconnectedness: MNE strategy, city-regions, and disruption. Journal of International Business Studies, 51(8): 1199-1222.

Lundvall, B. -A. 1992. Introduction. In B. -A. Lundvall (Ed.), National systems of innovation-Toward a theory of innovation and interactive learning: 1-19. London: Pinter.

Mair, J., Marti, I., \& Ventresca, M. 2012. Building inclusive markets in rural Bangladesh: How intermediaries work institutional voids. Academy of Management Journal, 55(4): 819-850.

Mariotti, S., \& Piscitello, L. 2001. Localized capabilities and the internationalization of manufacturing activities by SMEs. Entrepreneurship and Regional Development, 13(1): 65-80.

Martinez-Noya, A., \& Narula, R. 2018. What more can we learn from R\&D alliances? A review and research agenda. BRQ Business Research Quarterly, 21(3): 195-212.

Mazzucato, M. 2016. From market fixing to market-creating: A new framework for innovation policy. Industry and Innovation, 23(2): 140-156.

Mazzucato, M. 2018. Mission-oriented innovation policies: Challenges and opportunities. Industrial and Corporate Change, 27(5): 803-815.

McCann, P., \& Mudambi, R. 2005. Analytical differences in the economics of geography: The case of multinational firm. Environment and Planning, 37(10): 1857-1876.

McDermott, G. A., \& Pietrobelli, C. 2017. Walking before you can run: The knowledge, networks and institutions for emerging market SMEs. In T. Pedersen, T. M. Devinney, L. Tihanyi, A. Camuffo (Ed.) Breaking up the global value chain: Opportunities and consequences. Advances in International Management (vol. 30). Bingley: Emerald Publishing Limited.

McDermott, G. A., Corredoira, R. A., \& Kruse, G. 2009. Publicprivate institutions as catalysts of upgrading in emerging market societies. Academy of Management Journal, 52(6): 1270-1296.

McEvily, B., \& Zaheer, A. 1999. Bridging ties: A source of firm heterogeneity in competitive capabilities. Strategic Management Journal, 20(12): 1133-1156.

Meyer, K. E., \& Peng, M. W. 2016. Theoretical foundations of emerging economy business research. Journal of International Business Studies, 47(1): 3-22.

Moran, P., \& Ghoshal, S. 1999. Markets, firms, and the process of economic development. Academy of Management Review, 24: 390-412.

Morck, R., Yeung, B., \& Yu, W. 2000. The information content of stock markets: Why do emerging markets have synchronous stock price movements? Journal of Financial Economics, 58(1-2): 215-260

Mudambi, R. 2008. Location, control and innovation in knowledge-intensive industries. Journal of Economic Geography, 8(5): 699-725.

Narula, R. 2002. Innovation systems and 'inertia' R\&D location: Norwegian firms and the role of systemic lock-in. Research Policy, 31(5): 795-816.

Narula, R. 2004. R\&D collaboration by SMEs: New opportunities and limitations in the face of globalization. Technovation, 24(2): 153-161.

Narula, R. 2012. Do we need different frameworks to explain infant MNEs from developing countries? Global Strategy Journal, 2: 188-204.

Narula, R. 2014. Exploring the paradox of competence-creating subsidiaries: Balancing bandwidth and dispersion in MNEs. Long Range Planning, 47(1-2): 4-15.

Narula, R. 2019. Enforcing higher labor standards within developing country value chains: Consequences for MNEs 
and informal actors in a dual economy. Journal of International Business Studies, 50(9): 1622-1635.

Narula, R., Asmussen, C., Chi, T., \& Kundu, S. 2019. Applying and advancing internalization theory: The multinational enterprise in the 21st century. Journal of International Business Studies, 50: 1231-1252.

Narula, R., \& Dunning, J. H. 1998. Explaining international R\&D alliances and the role of governments. International Business Review, 7(4): 377-397.

Narula, R., \& Dunning, J. H. 2000. Industrial development, globalization and multinational enterprises: New realities for developing countries. Oxford Development Studies, 28(2): 141-167.

Narula, R., \& Pineli, A. 2019. Improving the developmental impact of multinational enterprises: Policy and research challenges. Economia e Politica Industriale, 46(1): 1-24.

Narula, R., \& Santangelo, G. D. 2009. Location, collocation and R\&D alliances in the European ICT industry. Research Policy., 38(2): 393-403.

Narula, R., \& Verbeke, A. 2015. Making internalization theory good for practice: The essence of Alan Rugman's contributions to international business. Journal of World Business, 50(4): 612-622.

Narula, R., \& Van der Straaten, K. 2021. A comment on the multifaceted relationship between multinational enterprises and within-country inequality. Critical Perspectives on International Business, 17(1): 32-50. https://doi.org/10.1108/cpoib10-2019-0080.

Nelson, R. R. 2008. What enables rapid economic progress: What are the needed institutions? Research Policy, 37(1): 1-11.

OECD-ECLAC. 2013. SME policies for structural change. Latin American Economic Outlook 2013.

Owen-Smith, J., \& Powell, W. W. 2004. Knowledge networks as channels and conduits: The effects of spillovers in the Boston biotechnology community. Organization Science, 15(1): 5-21.

Padgett, J. F., \& Powell, W. W. 2012. The emergence of organizations and markets. Princeton: Princeton University Press.

Parente, R., Melo, M., Andres, D., Kumaraswamy, A., \& Vasconcelos, F. 2021. Public sector organizations and agricultural catch-up dilemma in emerging markets: The orchestrating role of Embrapa in Brazil. Journal of International Business Studies. https://doi.org/10.1057/s41267-020-00325-x.

Peng, M., Wang, D., \& Jiang, Y. 2008. An institution-based view of international business strategy: A focus on emerging economies. Journal of International Business Studies, 39(5): 920-936.

Perez-Aleman, P. 2010. Standards as institutions supporting the cluster emergence process: The case of aquaculture in Chile. In D. Fornahl, S. Henn, \& M. Menzel (Eds.), Emerging clusters, Cheltenham: Edward Elgar.

Perez-Aleman, P. 2011. Collective learning in global diffusion: Spreading quality standards in a developing country cluster. Organization Science, 22(1): 173-189.

Pietrobelli, C., \& Rabellotti, R. 2011. Global value chains meet innovation systems: Are there learning opportunities for developing countries? World Development, 39(7): 1261-1269.

Pineli, A., Narula, R., \& Belderbos, R. 2021. FDI, multinationals and structural change in developing countries. In N. FosterMcGregor, L. Alcorta, E. Szirmai, \& B. Verspagen (Eds.), New perspectives on structural change: 494-523. Oxford: Oxford University Press.

Pitelis, C. N., \& Teece, D. J. 2018. The new MNE: 'Orchestration' theory as envelope of 'Internalisation' theory. Management International Review, 58(4): 523-539.

Powell, W. W., White, D. R., Koput, K. W., \& Owen-Smith, J. 2005. Network dynamics and field evolution: The growth of interorganizational collaboration in the life sciences. American Journal of Sociology, 110(4): 1132-1205.
Radas, S., \& Božić, L. 2009. The antecedents of SME innovativeness in an emerging transition economy. Technovation, 29(6-7): 438-450.

Radjou, N., Prabhu, J., \& Ahuja, S. 2012. Jugaad innovation: A frugal and flexible approach to innovation for the 21st century. New Delhi: Random House India.

Reuer, J. J., \& Zollo, M. 2005. Termination outcomes of research alliances. Research Policy, 34(1): 101-115.

Rojec, M., \& Knell, M. 2018. Why is there a lack of evidence on knowledge spillovers from foreign direct investment? Journal of Economic Surveys, 32(3): 579-612.

Rosenkopf, L., \& Tushman, M. L. 1998. The coevolution of community networks and technology: Lessons from the flight simulation industry. Industrial and Corporate Change, 7(2): 311-346.

Rugman, A. 1980. A new theory of the multinational enterprise: Internationalization vs. internalization. Columbia Journal of World Business, 15(1): 23-29.

Rugman, A., \& D'Cruz, J. 1993. The "double diamond" model of international competitiveness: The Canadian experience. Management International Review, 33(S2): 17-39.

Santamaría, L., Nieto, M. J., \& Barge-Gil, A. 2009. Beyond formal R\&D: Taking advantage of other sources of innovation in low-and medium-technology industries. Research Policy, 38(3): 507-517.

Santangelo, G. D. 2000. Corporate strategic technological partnerships in the European information and communications technology industry. Research Policy, 29(9): 1015-1031.

Santangelo, G. D., Meyer, K. E., \& Jindra, B. 2016. MNE subsidiaries' outsourcing and insourcing of R\&D: The role of local institutions. Global Strategy lournal, 6(4): 247-268.

Schotter, A., Mudambi, R., Doz, Y., \& Gaur, A. 2017. Boundary spanning in global organizations. Journal of Management Studies, 54(4): 403-421.

Schumpeter, J. A. 1934. The theory of economic development. Cambridge: Harvard University Press.

Schumpeter, J. A. 1942. Capitalism, socialism, and democracy. New York: Harper \& Brothers.

Shapiro, D., Hobdari, B., Peng, M., \& Oh, C. H. 2018. Multinational enterprises and sustainable development in the extractive and natural resource sectors. Journal of World Business, 53(1): 1-14.

Shenkar, O. 2010. Copycats: How smart companies use imitation to gain a strategic edge. Strategic Direction, 26(10): 3-5.

Sun, P. Deng, Z., \& Wright, M. 2021. Partnering with Leviathan: The politics of innovation in foreign-host-state joint ventures. Journal of International Business Studies. https://doi. org/10.1057/s41267-020-00340-y.

Szulanski, G. 1996. Exploring internal stickiness: impediments to the transfer of best practice within the firm. Strategic Management Journal, 17(S2): 27-43.

Tushman, M. L., \& Nadler, D. A. 1978. Information processing as an integrating concept in organizational design. Academy of Management Review, 3(3): 613-624.

Un, C. A., \& Rodríguez, A. 2018. Local and global knowledge complementarity: $R \& D$ collaborations and innovation of foreign and domestic firms. Journal of International Management, 24(2): 137-152.

UNCTAD 2013. World investment report: Global value chains investment and trade for development. New York: United Nations.

Van de Vrande, V., De Jong, J. P., Vanhaverbeke, W., \& De Rochemont, M. 2009. Open innovation in SMEs: Trends, motives and management challenges. Technovation, 29(6-7): 423-437.

Van Wijk, R., Jansen, J. J., \& Lyles, M. A. 2008. Inter-and intraorganizational knowledge transfer: A meta-analytic review and assessment of its antecedents and consequences. Journal of Management Studies, 45(4): 830-853. 
Vasudeva, G., \& Anand, J. 2011. Unpacking absorptive capacity: A study of knowledge utilization from alliance portfolios. Academy of Management Journal, 54(3): 611-623.

Verbeke, A. 2009. International business strategy. Cambridge: Cambridge University Press.

Witt, M. A. 2019. De-globalization: Theories, predictions, and opportunities for international business research. Journal of International Business Studies, 50(7): 1053-1077.

$\mathrm{Wu}$, J., \& Park, S. H. 2019. The role of international institutional complexity on emerging market multinational companies' innovation. Global Strategy Journal, 9(2): 333-353.

Zhao, M. 2006. Conducting R\&D in countries with weak intellectual property rights protection. Management Science, 52(8): 1186-1199.

Zhao, Z., \& Anand, J. 2013. Beyond boundary spanners: The 'collective bridge' as an efficient interunit structure for transferring collective knowledge. Strategic Management Journal, 34(13): 1513-1530.

Zhao, Z., Anand, J., \& Mitchell, W. 2005. A dual networks perspective on inter-organizational transfer of R\&D Capabilities: International joint ventures in the Chinese automotive industry. Journal of Management Studies, 42(1): 127-160.

Zollo, M., \& Winter, S. G. 2002. Deliberate learning and the evolution of dynamic capabilities. Organization Science, 13(3): 339-351.

\section{ABOUT THE AUTHORS}

Jaideep Anand is William H. Davis Chair and Dean's Distinguished Professor of Strategy at the Fisher College, Ohio State University, USA. He earned his BTech from the Indian Institute of Technology and PhD from the Wharton School. His service includes roles as chair of AOM (IM division), Senior Editor at Organization Science, Associate Editor at GSJ and Consulting Editor at JIBS.

Gerald McDermott is Professor of International Business at the Darla Moore School of Business,
University of South Carolina, USA, and Director of the Folks Center for International Business. He is also Senior Research Fellow at IAE Business School, Argentina. He specializes in international business and political economy, particularly on issues of innovation, risk, corporate strategy, and institutional change in emerging countries.

Ram Mudambi is the Frank M. Speakman Professor of Strategy at the Fox School of Business, Temple University, USA. His research focuses on the geography of innovation, with a recent emphasis on issues of migration, ethnicity and gender. He is currently Co-Editor of the Global Strategy Journal, an Area Editor of the Journal of International Business Policy and a Consulting Editor of JIBS.

Rajneesh Narula is the John H. Dunning Chair of International Business Regulation at the Henley Business School, University of Reading, UK. His research and consulting have focused on the role of multinational firms in economic development, innovation and industrial policy, informality, R\&D alliances and outsourcing. He is currently an Editor of JIBS, and Editor-in-Chief of the Journal of Industrial and Business Economics.

Publisher's Note Springer Nature remains neutral with regard to jurisdictional claims in published maps and institutional affiliations.

Accepted by Alain Verbeke, Editor-in-Chief, 7 March 2021. This article has been with the authors for one revision and was single-blind reviewed. 